\title{
Climate change undermines the global functioning of marine food webs
}

Du Pontavice, Hubert; Gascuel, Didier; Reygondeau, Gabriel; Maureaud, Aurore; Cheung, William W.L.

Published in:

Global Change Biology

Link to article, DOI:

$10.1111 / \mathrm{gcb} .14944$

Publication date:

2020

Document Version

Peer reviewed version

Link back to DTU Orbit

Citation (APA):

Du Pontavice, H., Gascuel, D., Reygondeau, G., Maureaud, A., \& Cheung, W. W. L. (2020). Climate change undermines the global functioning of marine food webs. Global Change Biology, 26(3), 1306-1318. https://doi.org/10.1111/gcb.14944

\section{General rights}

Copyright and moral rights for the publications made accessible in the public portal are retained by the authors and/or other copyright owners and it is a condition of accessing publications that users recognise and abide by the legal requirements associated with these rights.

- Users may download and print one copy of any publication from the public portal for the purpose of private study or research.

- You may not further distribute the material or use it for any profit-making activity or commercial gain

- You may freely distribute the URL identifying the publication in the public portal 
DR. HUBERT DU PONTAVICE (Orcid ID : 0000-0001-9571-0651)

DR. WILLIAM CHEUNG (Orcid ID : 0000-0001-9998-0384)

Article type : Primary Research Articles

\section{Climate change undermines the global functioning of marine food webs}

Hubert du Pontavice ${ }^{1,2, *}$, Didier Gascuel ${ }^{1}$, Gabriel Reygondeau ${ }^{2,3,4}$, Aurore Maureaud ${ }^{5}$, William W. L. Cheung ${ }^{2}$

${ }^{1}$ ESE, Ecology and ecosystem health, Agrocampus Ouest, Rennes, France,

2 Changing Ocean Research Unit and Nippon Foundation-the University of British Columbia Nereus Program, Institute for the Oceans and Fisheries, University of British Columbia, Vancouver, British Columbia, Canada

${ }^{3}$ Institute for the Oceans and Fisheries, University of British Columbia, Vancouver, British Columbia, Canada

${ }^{4}$ Department of Ecology and Evolutionary Biology Max Planck, Yale Center for Biodiversity Movement and Global Change, Yale University, New Haven, USA

${ }^{5}$ Centre for Ocean Life, National Institute of Aquatic Resources (DTU Aqua), Technical University of Denmark, Kemitorvet Building 202, 2800 Kgs. Lyngby, Denmark

* Contact author, E-mail: hubert.dupontavice@agrocampus-ouest.fr, Phone number: +33 78336 1992

Keywords: Marine Food Web, Species Assemblage, Biomass Flow, Trophic Transfer Efficiency, Biomass Residence Time, Climate Change, Trophic Ecology, Ecosystem Modelling.

This article has been accepted for publication and undergone full peer review but has not been through the copyediting, typesetting, pagination and proofreading process, which may lead to differences between this version and the Version of Record. Please cite this article as doi: $\underline{10.1111 / G C B .14944}$

This article is protected by copyright. All rights reserved 


\section{Abstract}

Sea water temperature affects all biological and ecological processes that ultimately impact ecosystem functioning. In this study, we examine the influence of temperature on global biomass transfers from marine secondary production to fish stocks. By combining fisheries catches in all coastal ocean areas and life history traits of exploited marine species, we provide global estimates of two trophic transfer parameters which determine biomass flows in coastal marine food web: the trophic transfer efficiency and the biomass residence time in the food web. We find that biomass transfers in tropical ecosystems are less efficient and faster than in areas with cooler waters. In contrast, biomass transfers through the food web became faster and more efficient between 1950 and 2010. Using simulated changes in sea water temperature from three Earth system models, we project that the mean trophic transfer efficiency in coastal waters would decrease from $7.7 \%$ to 7.2\% between 2010 and 2100 under the 'no effective mitigation' Representative Concentration Pathway (RCP 8.5), while biomass residence time between trophic level 2 and 4 is projected to decrease from 2.7 to 2.3 year on average. Beyond the global trends, we show that the trophic transfer efficiencies and biomass residence times may vary substantially among ecosystem types and that the polar ecosystems may be the most impacted ecosystems. The detected and projected changes in mean trophic transfer efficiency and biomass residence time will undermine food web functioning. Our study provides quantitative understanding of temperature effects on trophodynamic of marine ecosystems under climate change.

This article is protected by copyright. All rights reserved 


\section{Introduction}

In marine ecosystems, temperature is one of the main factors affecting species physiology (Cheung, Watson, \& Pauly, 2013; Pörtner \& Farrell, 2008), biogeography (Tittensor et al., 2010), trophic dynamics (Boyce, Frank, Worm, \& Leggett, 2015; Pörtner et al., 2014), and ecosystem services such as food provision. A growing number of studies have shown that modifications of the natural fluctuation of ocean temperature have caused shifts in the geographic distribution of marine species and phenology from plankton to top predators (Beaugrand, Edwards, \& Legendre, 2010; Cheung et al., 2009; Dulvy et al., 2008; Perry, 2005; Pinsky, Worm, Fogarty, Sarmiento, \& Levin, 2013; Poloczanska et al., 2013). These biogeographical shifts have resulted in reorganization of marine species assemblages in various ecosystems across the global ocean (Beaugrand et al., 2014; Kortsch et al., 2018; Kortsch, Primicerio, Fossheim, Dolgov, \& Aschan, 2015) and influenced the composition of fisheries catches (Cheung et al., 2013; Stuart-Smith, Edgar, Barrett, Kininmonth, \& Bates, 2015).

At the individual scale, warmer temperature results in faster exothermic biogeochemical reactions and higher metabolic rates (Brown, Gillooly, Allen, Savage, \& West, 2004a; Bruno, Carr, \& O'Connor, 2015). Consequently, warmer temperature conditions may induce an increase in the speed of biomass transfer in the food web and a reduction of the biomass residence time. In addition, higher organism metabolic rates imply larger losses by respiration, and may cause a decrease in the efficiency of biomass transfers by affecting growth (Barneche \& Allen, 2018; Heilmayer, Brey, \& Pörtner, 2004; Palomares \& Pauly, 1998; Pörtner, Peck, \& Somero, 2012). These changes at the individual level are expected to propagate at the population and hence community levels (Barneche \& Allen, 2018; Brown, Gillooly, Allen, Savage, \& West, 2004b; Bruno et al., 2015; Pinsky, Selden, \& Kitchel, 2020; Schramski, Dell, Grady, Sibly, \& Brown, 2015).

In particular, changes in species composition induced by warmer waters may result in the selection of species characterized by shorter lifespan and higher respiration rates at every level of the food web, therefore leading to faster and less efficient biomass transfers, respectively. Several studies suggest profound reshuffles of marine communities due to anthropogenic changes in ocean conditions (Cheung et al., 2009; Pachauri, Mayer, \& IPCC, 2015; Pereira et al., 2010; Pörtner et al., 2014; Rutterford et al., 2015). However, the consequences of ocean warming on properties of biomass flow remain unexplored and unquantified.

This article is protected by copyright. All rights reserved 
Here, we used a trophodynamic approach, initially developed by Lindeman (1942), to analyse the impact of sea water temperature on biomass flowing in ecosystems, from primary consumer to top predators. Two parameters summarize these biomass transfers through the food web and are expected to change in a warming ocean: the trophic transfer efficiency and the biomass residence time. Trophic transfer efficiency (TTE) is the fraction of energy transferred from one trophic level to the next and summarises all the losses in the food web at each trophic level (Jennings, Warr, \& Mackinson, 2002; Libralato, Coll, Tudela, Palomera, \& Pranovi, 2008; Lindeman, 1942; Niquil et al., 2014; Pauly \& Christensen, 1995; Schramski et al., 2015; Stock et al., 2017; Strayer, 1991). TTE is measured as the ratio between the production rate of two adjacent trophic levels (Baumann, 1995; Libralato et al., 2008; Lindeman, 1942; D. Pauly \& Christensen, 1995; Ricklefs \& Miller, 2000). This property of the food web has been widely studied (Andersen, Beyer, \& Lundberg, 2009; Chassot et al., 2010; Irigoien et al., 2014; Jennings et al., 2008; Stock et al., 2017) and some studies suggest that it spatially varies among biomes or ecosystem types (Chassot et al., 2010; Libralato et al., 2008; Schramski et al., 2015; Stock et al., 2017).

Biomass residence time (BRT) is the average amount of time a unit of biomass spends at a given trophic level before trophic transfer to higher trophic levels in the food web through predation (Gascuel, Morissette, Palomares, \& Christensen, 2008; Schramski et al., 2015). BRT (expressed in years) is inversely proportional to the speed of biomass transfer across trophic levels. It directly affects the biomass present at each trophic level of the food web (longer residence time results in greater biomass at each trophic level).

The aim of this study is to analyse how the temperature-induced spatial patterns in species composition affect biomass transfers in marine food webs, and how these transfers are expected to change over the $21^{\text {st }}$ century. We focus on community-level biological responses driven by changes in species assemblages. The study and analysis are performed for the coastal regions of the global ocean which currently support the bulk of fisheries production, and where catch data are used as insights on the features of the marine community structure.

First, we measure TTE and BRT based on fisheries catch species composition over the period 2000-2010 and determine how these two parameters vary along the temperature gradient in the global coastal marine ecosystems. Second, to detect the past changes in biomass transfers and determine if ocean warming has already affected them, we analyse the trends in TTE and BRT between 1950 and 2010 and we compare the observed and modelled trends using sea water temperature data. Finally, we project TTE and BRT by 2100 using simulated changes in sea water 


\section{Materials and Methods}

\section{Study area and catch data}

Since the composition of species assemblages is unknown in many coastal marine ecosystems that we studied, we estimated trophic transfer parameters based on catch data, assuming they can be considered as proxy of the true features of the food web. This assumption will be further discussed and sensitivity analyses were conducted.

Annual reconstructed catch data made available by the SeaAroundUs project from 1950 to 2010 (Pauly and Zeller, 2015) were used. This set of data is spatially disaggregated by taxon on a $1^{\circ} \mathrm{x}$ $1^{\circ}$ spatial grid of the world ocean. The reconstruction is based on the official records from the Food and Agriculture Organization (FAO), with addition of undeclared artisanal and subsidence fisheries, recreational catches, discarded bycatch and illegal and unreported catch (Pauly and Zeller, 2015).

We removed catch of rare taxa representing less than $0.05 \%$ of the total catches for each year and catches from unidentified species. Biogeography of coastal and shelf areas were delimited using the distribution of coastal biomes identified by Reygondeau et al. (2013) and adapted from Longhurst (2007). To ensure that parameters issued from the catch composition in each grid cell is representative of the food web, we removed grid cells where unidentified species represented more than $50 \%$ of the total catch, and cells where one single species represented more than $75 \%$ of the catch. Finally, we kept only grid cells where there were more than 10 species excluding rare taxa. After passing the dataset through the above filters, the final dataset consists of 5,783 (75\% of the cells) $1^{\circ}$ latitude $\times 1^{\circ}$ longitude grid cells and 1760 taxa in coastal and shelf seas. Each cell was classified as one of the 3 biomes: tropical, temperate and polar biomes. Upwelling ecosystems were added using the biogeographical provinces described by Reygondeau et al., (2013) (Figure 1).

\section{Trophic transfer efficiency and biomass residence time calculations}

Trophic transfer efficiency (TTE) and biomass residence time (BRT) were estimated within each grid cell using a trophodynamic approach based on two indicators: the efficiency cumulated indicator (ECI) and the time cumulated indicator (TCI). The method to calculate TTE and BRT is summarised in Figure 2.

a. Trophic transfer efficiency (TTE)

This article is protected by copyright. All rights reserved 
The efficiency cumulated indicator (ECI) developed by Maureaud et al., (2017) quantifies the fraction of secondary production transferred from trophic level (TL) 2 to 4, considering only metabolism losses due to respiration and excretion (see partial transfer efficiency (partial TE on Figure 3)). It was calculated for each grid cell $i$ and each year $y$, as an aggregation from TL $=2$ to $\mathrm{TL}=4$ of the production to consumption ratio $(\mathrm{P} / \mathrm{Q})_{\tau, \mathrm{i}, \mathrm{y}}$ which can be defined as the "gross food conversion efficiency" (Christensen \& Pauly, 1993) at trophic level $\tau$, with the following equations:

$$
E C I_{i, y}=\prod_{\tau=2.0}^{4.0}\left(\left(\frac{P}{Q}\right)_{\tau, i, y}\right)
$$

Eq. 1

$\mathrm{P} / \mathrm{Q}$ is firstly calculated for each species or taxon $j$, as the ratio of $\mathrm{P} / \mathrm{B}$ (Production to Biomass) to Q/B (Consumption to Biomass). For finfish, these taxon-specific ratios are calculated according to the empirical equations of Gascuel et al. (2008) and Palomares and Pauly (1998) and based on life history traits and thermal habitat (see Supporting Information Appendix S1). The required data (asymptotic weight, Von Bertalanffy growth coefficient, diet type and aspect ratio) were taken from FishBase (http://www.fishbase.org, Froese and Pauly, 2018). For the others species (e.g., cephalopods, crustaceans), the taxon-specific $\mathrm{P} / \mathrm{B}$ and $\mathrm{P} / \mathrm{Q}$ ratios were extracted from EcoBase (Colléter et al., 2013) (see Supporting Information Appendix S1).

Then, taxon-specific $\mathrm{P} / \mathrm{Q}$ ratios were transformed into a $\mathrm{P} / \mathrm{Q}$ trophic spectra (Gascuel, Bozec, Chassot, Colomb, \& Laurans, 2005). To consider the within-taxon variability of trophic levels, catches of every taxon were distributed over a range of trophic classes (following a lognormal distribution and using classes with a width of $0.1 \mathrm{TL}$ ). Trophic spectra were obtained by averaging the taxon-specific $\mathrm{P} / \mathrm{Q}$ ratios weighted by the resulting catch per taxon and trophic class.

Since the ECI calculation does not account for losses in trophic transfers related to non-predation natural mortality and biomass accumulation, ECI is measuring a partial transfer efficiency, and is likely to overestimate the true trophic transfer efficiency (TTE). To account for such overestimation, partial transfer efficiency was converted into TTE by introducing a correction term based on Ecotrophic Efficiency (EE, Christensen \& Pauly, 1992) and $B_{\text {acc }}$ (biomass accumulation rate within each species or taxon). Thus, $\left(\mathrm{EE}-\mathrm{B}_{\mathrm{acc}}\right)$ measures the fraction of the production of a given taxon not transferred to detritus and not accumulated by the taxon, and thus available for trophic transfers through consumption by predators (see theoretical graph on Figure

3). $E E$ and $B_{\text {acc }}$ were extracted from coastal Ecopath models (see Supporting Information

This article is protected by copyright. All rights reserved 
Appendix S2) included in the EcoBase database (Colléter et al., 2013). The extracted data were then used to calculate a correction factor for each trophic level $\tau$ and for each ecosystem type $\beta$ (see Supporting Information Appendix S3). Finally, the two components of TTE - the fraction of loss due metabolism $(\mathrm{P} / \mathrm{Q})$ and the non-predation natural mortality and biomass accumulation (EE$B_{a c c}$ ) - are combined. Thus, the trophic transfer efficiency between $T L=2$ and $T L=4$, can be estimated as a product of all trophic classes; the estimates, which represent TTE across two trophic levels, is transformed into TTE expressed per trophic level by taking a square root of the term (Eq.2):

$$
T T E_{i, y}=\left[\prod_{\tau=2.0}^{4.0}\left(\left(\frac{P}{Q}\right)_{\tau, i, y} \cdot\left(E E-B_{a c c}\right)_{\tau, \beta}\right)\right]^{\frac{1}{2}}
$$

\section{b. Biomass residence time (BRT)}

The BRT, which is called the time cumulated indicator (TCI) by Maureaud et al. (2017), was calculated by aggregating the time spent by each unit of biomass within small trophic level classes of $\Delta_{\tau}=0.1 \mathrm{TL}$, when moving into the food web from trophic level 2 to 4 . Gascuel et al., (2008) showed that the mean speed of the biomass flow passing through a given trophic level can be measured as the production to biomass ratio $(\mathrm{P} / \mathrm{B})$. Therefore, as a speed is defined by a distance divided by a time, the time a unit of biomass need on average to cross a trophic class from $\mathrm{TL}=\tau$ to $\mathrm{TL}=\tau+\Delta \tau$ is equal to $\Delta \tau /(\mathrm{P} / \mathrm{B})$. Thus, the $\mathrm{BRT}$ between $\mathrm{TL}=2$ and $\mathrm{TL}=4$, can be estimated as a sum for all trophic classes, according to:

$$
B R T_{i, y}=\sum_{\tau=2.0}^{4.0} \frac{\Delta_{\tau}}{\left(\frac{P}{B}\right)_{\tau, i, y}}
$$

where BRT is the biomass residence time in the food web, between tropic levels 2 and 4, for cell $i$ and year $y$. $\mathrm{P} / \mathrm{B}$ ratio was first calculated by species or taxon (see Supporting Information Appendix S2), and converted into P/B trophic spectra using the above described method, thus providing an estimate for every trophic class.

c. Data used for the calculations

TTE and BRT were calculated for each year between 1950 and 2010 in each grid cells. This computation is using the annual catch species composition from the SeaAroundUs database. Trophic levels for each species or taxon were obtained from Fishbase and SeaLifeBase 
(http://www.sealifebase.org, Palomares and Pauly, 2018). We used sea surface temperature (SST) to estimate the thermal habitat of fish required to calculate the taxon-specific ratios (see Supporting Information Appendix S1) for every year between 1982 and 2010 from NOAA, using the Optimum Interpolation (OI) V2 dataset derived from in situ and satellite SST's (https://www.esrl.noaa.gov/psd/data/gridded/data.noaa.oisst.v2.html).

\section{Relationships between temperature, trophic transfer efficiency and biomass residence time}

In order to understand how the two trophic transfer parameters vary spatially and to determine their relationship to temperature in the recent past, the average values over the period 2000-2010 of TTE and BRT were estimated in each cell. Then, two generalized linear models (GLM), with TTE and BRT per grid cell as the dependent variables and sea water temperature as independent variable, were developed. The models consider an ecosystem type effect (tropical, temperature, polar or upwelling), in order to highlight potential non-temperature related differences in ecosystem structure. The interaction between sea water temperature and ecosystem type is also integrated in the models to take into account the differences in temperature effects among the four ecosystem types.

All statistical analyses were performed with the $\mathrm{R}$ free software environment (v.3.4.4, http://cran.r-project.org). The best-fitted family distribution and link function were selected among Gamma distribution (with identity, logarithmic and inverse link function), inverse Gaussian distribution (with identity, logarithmic and inverse link function), and Gaussian distribution (with identity and inverse link function) with log-transformed dependent variable or not. We finally chose to select models based on a Gaussian distribution on log-transformed trophic transfer parameters:

$\log (X)=$ Intercept $+S S T+$ ecosytem type $+S S T \cdot$ ecosytem type $+\varepsilon$ with $\varepsilon=N\left(0, \sigma^{2}\right)$.

$\mathrm{X}$ is TTE or BRT and $\varepsilon$ is the normally distributed error with mean of 0 and variance of $\sigma^{2}$.

Adequacy of the GLMs was evaluated by checking the distribution of model residuals for homoscedasticity, normality, the fraction of deviance explained by the model, and by each variable. The significance of the parameters was assessed using Wald chi-square tests. Laurent's correction was applied to the models to obtain unbiased estimations from log-transformed data (Laurent, 1963).

This article is protected by copyright. All rights reserved 


\section{Past and projected trends in trophic transfer efficiency and biomass}

\section{residence time}

In order to contrast projections over the 21 th century against the past variability and trends, TTE and BRT were estimated from 1950 to 2010, based on the fisheries catch species compositions. These observed past trends were compared to temperature-based estimates using the GLM statistical model. Then, we projected TTE and BRT by 2100 in the four ecosystem types, using yearly values of SST predictions from three Earth System Models, respectively developed by: the Geophysical Fluid Dynamics Laboratory (GFDL-ESM2M, Dunne et al., 2012), the Max Plank Institute (MPI-ESM-MR, Giorgetta et al. 2013) and the Institut Pierre Simon Laplace (IPSLCM5A-MR, Dufresne et al. 2013). Spatial distribution of ecosystem types was assumed unchanged by 2100 . Final projections of TTE and BRT were built by averaging results from the three general circulation models, under two contrasted Representative Concentration Pathways (RCPs, i.e. climate change scenarios from IPCC; http://sedac.ipccdata.org/ddc/ar5_scenario_process/RCPs.html): RCP2.6 where radiative forcing level reaches 3.1 $\mathrm{W} / \mathrm{m}^{2}$ by mid-century and returns to $2.6 \mathrm{~W} / \mathrm{m} 2$ by 2100 (strong mitigation scenario), and RCP8.5 where rising radiative forcing pathway reaches $8.5 \mathrm{~W} / \mathrm{m}^{2}$ in 2100 (no effective mitigation scenario).

\section{Sensitivity analysis}

TTE and BRT time are studied here using post-filtered catch data (see Study area and catch data in Materials and Methods), assuming that the features of the biomass flow of the exploited fraction of marine food webs reflect the features of the biomass flow of the entire marine food web. We recognize that the use of catch data to describe marine ecosystem functioning and structure may lead to biased estimators, due to selective fisheries and changes in the fishing strategies over time and space (Branch et al., 2010; Daniel Pauly, Hilborn, \& Branch, 2013). To evaluate the potential effects of these biases, two sensitivity analyses were conducted (Supporting Information Appendix S4 and S5). First, we tested the robustness of our models by adding the effects of the catch per surface area (as an indicator of the fishing intensity) and the mean trophic level of catch (MTL, as an indicator of the fishing strategy at the ecosystem level). Second, we used a selection of Ecopath ecosystem models to compare the estimates of the trophic transfer parameters based on species assemblages in the ecosystems or in the catch.

This article is protected by copyright. All rights reserved 
Since we estimated the two trophic transfer parameters from the $\mathrm{TL}=2$ to $\mathrm{TL}=4$ based on catch data, a large fraction of the biomass at lower levels is made up of species such as zooplankton, benthic invertebrates, or larvae not targeted by fishing. Thus, in our catch dataset, species less than or equal to TL of 2.5 represent only between 4 and $8 \%$ of the annual global catch. As a consequence, the catch composition between $\mathrm{TL}=2$ and $\mathrm{TL}=2.5$ is unable to reflect the species composition in the ecosystem, what may also lead to bias in our estimates. This potential bias was tested by modelling the temperature effect on the two trophic transfer parameters using only catches between $\mathrm{TL}=2.5$ and $\mathrm{TL}=4$ (Supporting Information Appendix S6).

Our data, TTE and BRT are spatially autocorrelated. This autocorrelation is supposed to be captured by the models. Nevertheless, if a spatial autocorrelation remains in the residuals of the GLMs, the key assumption that residuals are independent and identically distributed is violated, and parameter estimates may be biased. Consequently, we tested the potential spatial autocorrelation bias on our models by comparing the developed models and models based on 100 subsamples with no or a weak spatial autocorrelation (Supporting Information Appendix S7).

Finally, the natural non-predation mortality was taken into account in our analysis by adding a correction which reduces the TTE values. The correction is calculated on the average of ecotrophic efficiency and biomass accumulation by aggregating 72 Ecopath models per ecosystem type. Since these parameters may be modelling dependent and inaccurate in some models, we tested the introduction of this supplementary loss in the model by comparing the sea temperature effect including or not this correction (Supporting Information Appendix S3).

This article is protected by copyright. All rights reserved 


\section{Results}

\section{Relation between sea surface temperature and ecosystem trophodynamics}

Trophic transfer efficiency (TTE) and biomass residence time (BRT) over the recent period 20002010 differ significantly according to ecosystem type ( $p$-value $<0.001$ ). Polar ecosystems exhibit the most efficient but the slowest biomass transfers with a TTE of 10.4\% \pm 2.7 and BRT of 4.4 years \pm 1.3 between trophic level 2 and 4 (Figure $4 \mathrm{a}$ and $\mathrm{b}$ ). In contrast, trophic transfers in upwelling and tropical ecosystems appear faster with 2.8 years \pm 2.2 and 1.9 years \pm 1.9 respectively but less efficient with $5.9 \% \pm 0.7$ and $6.5 \% \pm 0.6$. Intermediate values are estimated in temperate ecosystems with 2.8 years \pm 0.9 and $8.1 \% \pm 2.4$.

The same spatial patterns emerged for the two trophic transfer parameters (see related maps on Figure 5a and b). In the colder coastal waters, for example in the Bering Sea and in the Antarctica coast, TTE and BRT exhibit high values, while in the warmer waters for example along the African coast and in the continental shelf of Southeast Asia, biomass is transferred faster and less efficiently. Some exceptions exist, such as in the Gulf of Mexico, which exhibits high TTE values, and in the Indian Ocean between the area between Seychelles and Mauritius showing a high BRT. Our models indicate that SST and ecosystem type have both a statistically significant effect on the studied biomass flow parameters. Furthermore, SST explained $34.7 \%$ and $48.7 \%$ of the total deviance for TTE and BRT respectively, while the interaction between SST and the ecosystem type explained an additional $5.4 \%$ and $2.3 \%$ for these two parameters (see Supporting Information Appendix S8).

The decreasing relationship between sea temperature and TTE or BRT is consistent across ecosystems types, although the variations in temperature sensitivity of these food web parameters between the ecosystem types were not expected (Figure $4 \mathrm{c}$ and d). Temperature sensitivity for TTE is higher in temperate and upwelling zones, followed by polar and tropical ecosystems. In contrast, BRT is more sensitive to temperature in polar and tropical ecosystems followed by temperate and upwelling ecosystems.

Observed past trends in trophic transfer efficiency and biomass residence time

Over the period 1950-2010, the observed global mean of TTE, computed from the catch composition, significantly increased from $7.1 \%$ to $7.6 \%$ (Figure 6a, p-value linear model $<0.001$ ),

This article is protected by copyright. All rights reserved 
while BRT decreased from 2.5 to 2.2 years (Figure 6b, p-value linear model $<0.001$ ). The changes in TTE and BRT occurred mainly before the mid-1990s, then TTE stopped its increase and BRT decreased at a slower pace. These increasing TTE and decreasing BRT are observed in every ecosystem type (see Supporting Information Appendix S9) except for TTE in polar ecosystem where the estimates increased from 1950 to 1978 before a steep decrease at the beginning of the 1980s and then an increase until 2010. The outputs of the temperature-based model show that BRT should have decreased at a slower rate than observed, while the TTE should have decreased slightly in place of increasing. Thus, changes in the species composition of the catch have affected the observed parameters which cannot be explained only by the temperature effect. This suggests that faster and more efficient trophic transfers have resulted from direct fishing-induced impacts on species assemblages.

\section{Projections for the end of the century}

TTE and BRT should decrease until 2040, regardless of the climate scenario or the Earth system model considered (Figure 7a and b). From 2000 to 2040, global averages are projected to decrease slightly by $0.09 \%$ for TTE and by 0.09 year for BRT. After 2040, TTE and BRT remain stable in scenario RCP2.6, while the decrease accelerates for both indicators in scenario RCP8.5. Overall, under RCP8.5, we projected a $0.5 \%$ loss of TTE (from 7.7 to $7.2 \%$ ) and a 0.4 year decrease in BRT (from 2.7 to 2.3 years) over the period 2000-2100.

The geographical distributions of the projected changes in TTE and BRT under RCP8.5 scenario show that the two trophic transfer parameters should decrease everywhere by the end of the $21^{\text {st }}$ century (2100), with the largest changes expected at high latitudes (Figure $4 \mathrm{~g}$ and $\mathrm{h}$ ). In polar, upwelling and temperate ecosystems, the projected losses in TTE are around $0.8 \%$ by 2100 , while they are much lower around $0.2 \%$ in tropical ecosystems (Figure $7 \mathrm{c}$ ). The BRT will be more affected by ocean warming in polar ecosystems than in others, with more than a 1.0 year decrease by 2100 , compared to 0.4 year ( $\sim 5$ months) in tropical ecosystems, 0.2 year ( $\sim 2$ months) in temperate ecosystems, and almost no effect in upwelling ecosystems, on average (Figure 7d).

This article is protected by copyright. All rights reserved 


\section{Discussion}

Our results provide estimates of average TTE and BRT in coastal marine food webs, at the global scale and per ecosystem type. We show that human-induced changes in species assemblages may already have affected the functioning of coastal marine food webs and are expected to have greater impacts over the 21th century. Specifically, the trophodynamics of coastal marine ecosystems have already changed and are expected to amplify their rate of change in the coming decades.

\section{Less efficient and faster transfers in warm waters}

Our study shows that sea water temperature significantly influences biomass transfers through the food web in global coastal marine ecosystems. The warmest coastal ecosystems are characterised by low-efficient and fast biomass transfers through the food web. These characteristics indicate that species assemblages are dominated, at each trophic level, by species with low TTE because of large energy losses due to their metabolism processes that scale with temperature (Brown et al., 2004b; Schramski et al., 2015). Also, the BRT is shorter in tropical coastal ecosystems so the biomass transfer between a prey and its predator is faster at each trophic level. These trophic functioning properties may be explained by species assemblages where communities may be dominated by short-living and fast-growing species. In contrast, in polar and temperate ecosystems, biomass is transferred more efficiently and slowly, where a unit of biomass spends more time in the food web. Such trophodynamic properties may be explained by species assemblages dominated by long-living and slow-growing species in colder waters as suggested by several authors in polar ecosystems (e.g., Murphy et al., 2016; Peck, 2016; Pörtner, Storch, \& Heilmayer, 2005). As the biomass transfer indicators are calculated using trophic spectra, the observed contrasts between warm and cold waters do not result from the distribution of long or short-living species among food webs (more predator and less prey in cold waters), but from differences occurring at every trophic level (longer living preys and predators in cold waters in contrast to warm waters).

The natural non-predation mortality is an additional factor reducing TTE by introducing supplementary losses, although it appeared to have little effect on the differences in TTE between the ecosystem types (Appendix S3). Finally, the low TTE in upwelling is consistent with the literature (Coll, Libralato, Tudela, Palomera, \& Pranovi, 2008; Libralato et al., 2008) and may be due to the highly variable productivities of upwelling ecosystems. This lack in stability, which

This article is protected by copyright. All rights reserved 
characterises immature or disturbed ecosystems (sensus Odum 1969), is likely to result in a weakly structured food web with fast and inefficient biomass transfers.

\section{Robustness of the analysis}

As we use catch data to study TTE and BRT, fishing effort, in addition to temperature, might affect trophic flow in marine ecosystems. The assessment of the potential effects of the confounding factors from fishing shows that the temperature sensitivity of these indicators remains supported (Appendix S4 and S5). First, we found that the fishing intensity (catch per $\mathrm{km}^{2}$ ) and the fishing strategies (MTL) have only a small effect on TTE estimates while BRT estimates are more sensitive to fishing intensity (Information Appendix S4). However, the effects of sea water temperature and ecosystem type on BRT remained highly significant and qualitatively unchanged even after accounting for the effects of fishing. Secondly, based on data from the selected Ecopath models, the absolute values of BRT and TTE are overestimated and underestimated, respectively, when using catch data instead of biomass data (Appendix S5). However, here too, qualitative results regarding the temperature effect and the variability among ecosystem types remained consistent.

Furthermore, it appeared that the exclusion of the lowest trophic levels affects mainly cold waters and upwelling ecosystems, decreasing the estimated TTE and increasing BRT (Appendix S6). However, the variations due to the lower trophic levels of the food web do not modify the order of magnitude and the trends regarding sea water temperature and ecosystem type effects.

The potential bias due to the spatial autocorrelation is low for TTE with a slight effect in tropical ecosystems (Appendix S7). Regarding BRT, the effect is a bit stronger, suggesting that we underestimated BRT in temperate and tropical ecosystems (greater values without the spatial autocorrelation) and we underestimated the temperature effects in polar and tropical ecosystems (greater slopes without the spatial autocorrelation).

The introduction of the natural non-predation mortality as an additional loss in TTE estimates by adding a correction factor (Supporting Information Appendix S3) has a rather low effect on the GLMs outputs. It induces an overall decrease in TTE but that does not change substantially neither the temperature effect nor the differences between the ecosystem types. Even if it is imperfect especially because we use potentially biased modelled parameters, we consider that the inclusion of the correction is better than ignoring the additional losses.

This article is protected by copyright. All rights reserved 
More generally, the observed temperature effects and predicted changes in trophic transfer are likely to be underestimated because our study is taking into account only the effect of community structure on the ecosystem functioning. Additional ocean warming effects at individual and population level are also expected to change the trophic transfer in marine food webs.

\section{Towards faster and less efficient trophic transfers}

The global decrease in BRT and increase in TTE over the period 1950-2010 is likely partly driven by the global increase in fishing pressure as previously shown by Maureaud et al. (2017), who focused on quantifying the fishing effects on trophodynamics over the Large Marine Ecosystem. Majorities of fishing activities tend to select the targeted large and long-living species causing a decrease in their abundance compared to small species with fast life histories (Cheung, Watson, Morato, Pitcher, \& Pauly, 2007; Jennings, Greenstreet, \& Reynolds, 1999; Planque et al., 2010; Shephard et al., 2012). Our results suggest that the same fishing effects occur within each trophic class leading to shorter biomass residence time and less efficient energy transfer in marine food webs. Such a trend may be considered as an adaptive reaction to the fishing pressure (Maureaud et al. 2017), leading to more efficient, but simplified and potentially less resilient food web.

The global decreasing trend of TTE estimated using the modelled temperature-based GLM (Figure 6a) is not consistent with the observed TTE over the period 1950-2010. The opposition between observed and modelled trends can be derived from the dominant fishing pressure. The decrease in the modelled TTE is driven by ocean warming, while the increase in the observed TTE between 1950 and the mid-1990s can likely be attributed to the growing amount of fishing pressure (Maureaud et al., 2017; Daniel Pauly \& Zeller, 2016). Following Pauly \& Zeller, (2016), global fishing catch reached its maximal value in 1996 and stabilized until now. Therefore, the stabilization of TTE trend from the mid-1990s can be assumed to be caused by the effects of constant fishing catch over already exploited system and the growing effect of ocean warming (Beaugrand et al., 2019). In parallel, the decreasing trend in BRT between 1950 and the mid-1990s is consistent with the observed BRT (Figure 6b). However, the decrease in observed BRT is steeper between 1950 and the mid-1990s. That can be also attributed to the increasing fishing pressure. As for TTE, the trend in observed BRT stabilized between 2000 and 2010 probably due to the decreasing fishing effects and the growing effect of ocean warming.

In the coming decades, as ocean warming is expected to intensify and by hypothesising that global fishing pressure will stabilize, the trend in TTE may reverse and decrease (Figure 7a and c) while 
BRT may globally continue to decrease (Figure $7 \mathrm{~b}$ and d). Consequently, the greater losses of production between every trophic level due to the decrease in TTE and BRT in the food web may lead to a decrease in biomass and production at each trophic level.

Our projections of changes in trophic transfer functioning only result from the expected modifications in species assemblages induced by warming. At the species level, responses to warming may differ from one species to the other, depending on their thermal tolerance and life histories (Perry et al., 2010; Pörtner \& Peck, 2010), and leading to changes in their own productivity and/or biogeographical shifts of their spatial distribution. In addition, indirect effects due to changes in species interactions can enhance the changes in marine community structure and functioning (Bruno et al., 2015).

\section{Polar ecosystems: the more affected ecosystems?}

Ocean warming effects on the trophic transfer parameters exhibit substantial differences between ecosystem types. TTE and BRT in polar ecosystems are projected to strongly decrease by 2100 due to its high sensitivity to temperature (Figure 4). Such a high thermal sensitivity of TTE and BRT in polar ecosystems is likely due to the narrow thermal window of the polar species that inhabit in stable ecosystem (Peck, Webb, \& Bailey, 2004; Pörtner et al., 2014; Sunday, Bates, \& Dulvy, 2011). The changes in biomass transfer may be also exacerbated by the reshuffling of polar ecosystems structure induced by the observed and projected poleward shifts in species distribution and the expansion of subpolar/boreal communities with faster and less efficient biomass flow properties (Cheung et al., 2009; Frainer et al., 2017; García Molinos et al., 2016; Kortsch et al., 2015). In addition, although the complexity and the diversity of the planktonic food web in polar ecosystems is equivalent to temperate ecosystems (Michel et al., 2012; Smetacek \& Nicol, 2005), the relatively low coastal marine biodiversity of high trophic level species (Tittensor et al., 2010; Worm \& Lotze, 2016) may accelerate the rate of decline of polar species. Such declines of endemic and sea ice dependent species are already observed at some locations (e.g., krills in the Southern Ocean, Atkinson, Siegel, Pakhomov, \& Rothery, 2004). Besides, the effects of temperature may be also abrupt in polar ecosystems due to more frequent and extreme marine heatwaves (Frölicher, Fischer, \& Gruber, 2018).

Species inhabiting in tropical ecosystems has also a relatively narrow thermal window that could explain the high thermal sensitivity of BRT (Poloczanska et al., 2016). However, TTE in tropical ecosystem exhibits a low thermal sensitivity and thus a moderate projected decrease by 2100 . The

This article is protected by copyright. All rights reserved 
higher biodiversity in tropical ecosystem may help buffer the warming effects on biomass transfer at lower latitudes. Therefore, in tropical ecosystem the BRT is expected to largely decrease but the losses in production between each trophic level may be weakly impacted. However, as our projections are based on current temperatures, we likely underestimate the effects of ocean warming on tropical ecosystems since these ecosystems will experience unprecedentedly observed temperature level associated with more frequent and extreme marine heatwaves (Frölicher et al., 2018).

BRT in temperate ecosystem exhibits a low thermal sensitivity to ocean warming probably due to the wide thermal window of the marine species living in temperate regions, as the result of the high seasonal variability (Sunday et al., 2011). However, TTE is highly sensitive to temperature leading to a high projected decrease in TTE while BRT is projected to decrease moderately.

In summary, our results show that biomass transfers in marine food webs have globally become more efficient and faster over the period 1950-2010, which may be explained, at least partially, by the past increase in global fishing pressure. Such changes may have compensating effects on the whole ecosystem biomass, as faster transfers imply less biomass per trophic level while more efficient transfers is reducing the losses. We also found that temperature plays a key role to determine the properties of the biomass flow in marine coastal ecosystems. While warm coastal ecosystems are characterised by less efficient and fast biomass transfers, in colder coastal ecosystems, biomass transfers are slower and more efficient. Our model projections suggest that the increase in sea temperature is expected to shift the global ocean towards faster and less efficient biomass transfers by 2100 with especially drastic changes in polar ecosystems. These changes in trophic functioning have cumulative effects and will likely lead to a decrease in biomass through increasing losses of production at each trophic level, and decreasing BRT in the food web. Ultimately, they may severely affect the catch potential of fisheries across the globe by the end of the century.

This article is protected by copyright. All rights reserved 


\section{Acknowledgment}

We wish to thank the Nippon Foundation-UBC Nereus program for supporting the collaboration between Agrocampus Ouest, Rennes, and the University of British Columbia, Vancouver. Hubert du Pontavice, William W.L. Cheung and Gabriel Reygondeau acknowledge funding support from the Nippon Foundation-UBC Nereus Program. Aurore Maureaud has received funding from the VILLUM Foundation (research grant attributed to Martin Lindegren, No. 13159). This study was made possible by Vicky Lam who provided disaggregated SeaAroundUs data. We further thank Jerome Guitton for his technical support.

This article is protected by copyright. All rights reserved 


\section{List of legends}

Figure 1: (a) Map of the coastal areas represented in the dataset and associated to ecosystem types. The colours refer to the ecosystem types: polar (in blue), temperate (in orange), tropical (in red) and upwelling (in green). The four graphs (b), (c), (d), and (e) show the past reconstructed trends in sea surface temperature (SST) and the predicted trends under RCP8.5 scenario (business as usual scenario). Temperature is represented by mean values of SST coming from the three Earth System Models used in the study and described in Materials and Methods.

Figure 2: Synthetic schematic representation of the method to calculate trophic transfer efficiency and biomass residence time focused on the data that we used and the levels of ecological organisation (from species to trophic level to ecosystem). $n$ represents the number of species. ${ }^{1}$ (Froese and Pauly, 2018), ${ }^{2}$ (Colléter et al., 2013), ${ }^{3}$ (Gascuel et al., 2008; Palomares \& Pauly, 1998), ${ }^{4}$ (Pauly and Zeller, 2015).

Figure 3: Schematic representation of biomass flow parameters between two trophic levels. Black arrows represent energy transfers or losses. The prey has a trophic level $\tau$ and the predator has a trophic level $(\tau+1)$. The partial transfer efficiency (partial TE) $(P \tau+1 / Q \tau+1)$ and trophic transfer efficiency $(P \tau+1 / P \tau)$ are indicated (derived from Gascuel, Morissette, Palomares, \& Christensen, 2008; Maureaud et al., 2017).

Figure 4: The effect of temperature on the two trophic transfer parameters. The violin plots on the top panels represent the distribution of the mean values of the two trophic transfer parameters: (a) trophic transfer efficiency (TTE) and (b) biomass residence time (BRT) in each ecosystem type over the period 2000-2010. The colours refer to the ecosystem types: polar (in blue), temperate (in orange), tropical (in red) and upwelling (in green). In both panels (c) and (d), coloured solid lines represent the predicted values (i.e., the temperature effect) of TTE and BRT respectively, provided for each ecosystem type by the GLM model. The black dashed lines represent the predicted values of TTE and BRT by an additional GLM model considering only SST as a covariate. The shaded areas refer to the mean predicted value confidence intervals (95\%). 5783 grid cells were used to calculate the trends.

Figure 5: Trophic transfer efficiencies and biomass residence times in the coastal regions of the global ocean. The panels (a) and (b) represent the observed values over the period 2000-2010 while the other panels exhibit the predicted values from the General Linear Model for: the period

This article is protected by copyright. All rights reserved 
2000-2010 (c) and (d), and projected changes in 2090-2100 relative to 2000-2010 for climate change scenarios for RCP 2.6 (e, f), and RCP $8.5(g, h)$.

Figure 6: Past trends of trophic transfer parameters over the period 1950-2010. The dashed lines represent global mean values of the observed trophic transfer efficiency (TTE) (a) and biomass residence time (BRT) (b). Shaded areas refer to bootstrap confidence intervals at $95 \%$. Solid black lines represent theoretical global mean trends of TTE and BRT, computed using the GLM temperature-based model. Light grey lines are trends calculated using three Earth System Models (GFDL: Geophysical Fluid Dynamics Laboratory, MPI: Max Plank Institute, IPSL: Institut Pierre Simon Laplace). 2253 grid cells were used to calculate the trends.

Figure 7: The expected changes of trophic transfer at the global scale over the 21st century. Panel (a) shows the projections of trophic transfer efficiency (TTE) and panel (b) shows the projections of biomass residence time (BRT) in the coastal ecosystems between 2000 and 2100 under two climate change scenarios, RCP2.6 and RCP8.5 in green and red, respectively. The dark lines are the mean values of the trophic transfer parameters and the light lines are the values of each general circulation model. Panels (c) and (d) focus on RCP8.5 scenario (the business as usual scenario) and represent the changes in TTE (c) and BRT (d), relative to 2000-2010 for each ecosystem type. 4608 grid cells were used to calculate the trends.

This article is protected by copyright. All rights reserved 


\section{Bibliography}

Andersen, K. H., Beyer, J. E., \& Lundberg, P. (2009). Trophic and individual efficiencies of sizestructured communities. Proceedings of the Royal Society B: Biological Sciences, 276(1654), 109-114. https://doi.org/10.1098/rspb.2008.0951

Atkinson, A., Siegel, V., Pakhomov, E., \& Rothery, P. (2004). Long-term decline in krill stock and increase in salps within the Southern Ocean. Nature, 432(7013), 100-103. https://doi.org/10.1038/nature02996

Barneche, D. R., \& Allen, A. P. (2018). The energetics of fish growth and how it constrains foodweb trophic structure. Ecology Letters, 21(6), 836-844. https://doi.org/10.1111/ele.12947

Baumann, M. (1995). A comment on transfer efficiencies. Fisheries Oceanography, 4(3), 264-266. https://doi.org/10.1111/j.1365-2419.1995.tb00150.x

Beaugrand, G., Conversi, A., Atkinson, A., Cloern, J., Chiba, S., Fonda-Umani, S., ... Edwards, M. (2019). Prediction of unprecedented biological shifts in the global ocean. Nature Climate Change, 9(3), 237-243. https://doi.org/10.1038/s41558-019-0420-1

Beaugrand, G., Conversi, A., Chiba, S., Edwards, M., Fonda-Umani, S., Greene, C., ... Sugisaki, H. (2014). Synchronous marine pelagic regime shifts in the Northern Hemisphere. Philosophical Transactions of the Royal Society B: Biological Sciences, 370(1659), 20130272-20130272. https://doi.org/10.1098/rstb.2013.0272

Beaugrand, G., Edwards, M., \& Legendre, L. (2010). Marine biodiversity, ecosystem functioning, and carbon cycles. Proceedings of the National Academy of Sciences, 107(22), 10120-10124. https://doi.org/10.1073/pnas.0913855107

Boyce, D. G., Frank, K. T., Worm, B., \& Leggett, W. C. (2015). Spatial patterns and predictors of trophic control in marine ecosystems. Ecology Letters, 18(10), 1001-1011. https://doi.org/10.1111/ele.12481

Branch, T. A., Watson, R., Fulton, E. A., Jennings, S., McGilliard, C. R., Pablico, G. T., ... Tracey, S. R. (2010). The trophic fingerprint of marine fisheries. Nature, 468(7322), 431-435. https://doi.org/10.1038/nature09528

Brown, J. H., Gillooly, J. F., Allen, A. P., Savage, V. M., \& West, G. B. (2004a). TOWARD A METABOLIC THEORY OF ECOLOGY. Ecology, 85(7), 1771-1789. https://doi.org/10.1890/03-9000

This article is protected by copyright. All rights reserved 
Brown, J. H., Gillooly, J. F., Allen, A. P., Savage, V. M., \& West, G. B. (2004b). TOWARD A METABOLIC THEORY OF ECOLOGY. Ecology, 85(7), 1771-1789. https://doi.org/10.1890/03-9000

Bruno, J. F., Carr, L. A., \& O’Connor, M. I. (2015). Exploring the role of temperature in the ocean through metabolic scaling. Ecology, 96(12), 3126-3140. https://doi.org/10.1890/14-1954.1

Chassot, E., Bonhommeau, S., Dulvy, N. K., Mélin, F., Watson, R., Gascuel, D., \& Le Pape, O. (2010). Global marine primary production constrains fisheries catches. Ecology Letters, 13(4), 495-505. https://doi.org/10.1111/j.1461-0248.2010.01443.x

Cheung, W. W. L., Lam, V. W. Y., Sarmiento, J. L., Kearney, K., Watson, R., \& Pauly, D. (2009). Projecting global marine biodiversity impacts under climate change scenarios. Fish and Fisheries, 10(3), 235-251. https://doi.org/10.1111/j.1467-2979.2008.00315.x

Cheung, W. W. L., Watson, R., Morato, T., Pitcher, T., \& Pauly, D. (2007). Intrinsic vulnerability in the global fish catch. Marine Ecology Progress Series, 333, 1-12. https://doi.org/10.3354/meps333001

Cheung, W. W. L., Watson, R., \& Pauly, D. (2013). Signature of ocean warming in global fisheries catch. Nature, 497(7449), 365-368. https://doi.org/10.1038/nature12156

Christensen, V., \& Pauly, D. (1992). ECOPATH II - a software for balancing steady-state ecosystem models and calculating network characteristics. Ecological Modelling, 61(3-4), 169-185. https://doi.org/10.1016/0304-3800(92)90016-8

Christensen, V., \& Pauly, D. (1993). Trophic models of aquatic ecosystems. Makati, Metro Manila, Philippines : Copenhagen K., Denmark: International Center for Living Aquatic Resources Management; International Council for the Exploration of the Sea: Danish International Development Agency.

Coll, M., Libralato, S., Tudela, S., Palomera, I., \& Pranovi, F. (2008). Ecosystem Overfishing in the Ocean. PLoS ONE, 3(12), e3881. https://doi.org/10.1371/journal.pone.0003881

Colléter, M., Valls, A., Guitton, J., Lyne, M., Sánchez, F. A.-, Christensen, V., ... Pauly, D. (2013). EcoBase: A repository solution to gather and communicate information from EwE models. 69.

Dufresne, J.-L., Foujols, M.-A., Denvil, S., Caubel, A., Marti, O., Aumont, O., ... Vuichard, N. (2013). Climate change projections using the IPSL-CM5 Earth System Model: From CMIP3 to CMIP5. Climate Dynamics, 40(9-10), 2123-2165. https://doi.org/10.1007/s00382-012-1636-1

This article is protected by copyright. All rights reserved 
Dulvy, N. K., Rogers, S. I., Jennings, S., Stelzenmller, V., Dye, S. R., \& Skjoldal, H. R. (2008). Climate change and deepening of the North Sea fish assemblage: A biotic indicator of warming seas. Journal of Applied Ecology, 45(4), 1029-1039. https://doi.org/10.1111/j.1365-2664.2008.01488.x

Dunne, J. P., John, J. G., Adcroft, A. J., Griffies, S. M., Hallberg, R. W., Shevliakova, E., ... Zadeh, N. (2012). GFDL's ESM2 Global Coupled Climate-Carbon Earth System Models. Part I : Physical Formulation and Baseline Simulation Characteristics. Journal of Climate, 25(19), 6646-6665. https://doi.org/10.1175/JCLI-D-11-00560.1

Frainer, A., Primicerio, R., Kortsch, S., Aune, M., Dolgov, A. V., Fossheim, M., \& Aschan, M. M. (2017). Climate-driven changes in functional biogeography of Arctic marine fish communities. Proceedings of the National Academy of Sciences, 114(46), 12202-12207. https://doi.org/10.1073/pnas.1706080114

Froese, R., \& Pauly, D. (Éd.). (2000). FishBase 2000 : Concepts, design and data sources. Makati City, Philippines: ICLARM.

Frölicher, T. L., Fischer, E. M., \& Gruber, N. (2018). Marine heatwaves under global warming. Nature, 560(7718), 360-364. https://doi.org/10.1038/s41586-018-0383-9

García Molinos, J., Halpern, B. S., Schoeman, D. S., Brown, C. J., Kiessling, W., Moore, P. J., ... Burrows, M. T. (2016). Climate velocity and the future global redistribution of marine biodiversity. Nature Climate Change, 6(1), 83-88. https://doi.org/10.1038/nclimate2769

Gascuel, D., Bozec, Y., Chassot, E., Colomb, A., \& Laurans, M. (2005). The trophic spectrum : Theory and application as an ecosystem indicator. ICES Journal of Marine Science, 62(3), 443-452. https://doi.org/10.1016/j.icesjms.2004.12.013

Gascuel, D., Morissette, L., Palomares, M. L. D., \& Christensen, V. (2008). Trophic flow kinetics in marine ecosystems: Toward a theoretical approach to ecosystem functioning. Ecological Modelling, 217(1-2), 33-47. https://doi.org/10.1016/j.ecolmodel.2008.05.012

Giorgetta, M. A., Jungclaus, J., Reick, C. H., Legutke, S., Bader, J., Böttinger, M., ... Stevens, B. (2013). Climate and carbon cycle changes from 1850 to 2100 in MPI-ESM simulations for the Coupled Model Intercomparison Project phase 5: Climate Changes in MPI-ESM. Journal of Advances in Modeling Earth Systems, 5(3), 572-597. https://doi.org/10.1002/jame.20038

This article is protected by copyright. All rights reserved 
Heilmayer, O., Brey, T., \& Pörtner, H. O. (2004). Growth efficiency and temperature in scallops : A comparative analysis of species adapted to different temperatures. Functional Ecology, 18(5), 641-647. https://doi.org/10.1111/j.0269-8463.2004.00905.x

Irigoien, X., Klevjer, T. A., Røstad, A., Martinez, U., Boyra, G., Acuña, J. L., ... Kaartvedt, S. (2014). Large mesopelagic fishes biomass and trophic efficiency in the open ocean. Nature Communications, 5. https://doi.org/10.1038/ncomms4271

Jennings, S., Melin, F., Blanchard, J. L., Forster, R. M., Dulvy, N. K., \& Wilson, R. W. (2008). Global-scale predictions of community and ecosystem properties from simple ecological theory. Proceedings of the Royal Society B: Biological Sciences, 275(1641), 1375-1383. https://doi.org/10.1098/rspb.2008.0192

Jennings, Simon, Greenstreet, Simon. P. R., \& Reynolds, John. D. (1999). Structural change in an exploited fish community: A consequence of differential fishing effects on species with contrasting life histories. Journal of Animal Ecology, 68(3), 617-627. https://doi.org/10.1046/j.1365-2656.1999.00312.x

Jennings, Simon, Warr, K. J., \& Mackinson, S. (2002). Use of size-based production and stable isotope analyses to predict trophic transfer efficiencies and predator-prey body mass ratios in food webs. Marine Ecology Progress Series, 240, 11-20.

Kortsch, S., Primicerio, R., Aschan, M., Lind, S., Dolgov, A. V., \& Planque, B. (2018). Food-web structure varies along environmental gradients in a high-latitude marine ecosystem. Ecography. https://doi.org/10.1111/ecog.03443

Kortsch, S., Primicerio, R., Fossheim, M., Dolgov, A. V., \& Aschan, M. (2015). Climate change alters the structure of arctic marine food webs due to poleward shifts of boreal generalists. Proceedings of the Royal Society B: Biological Sciences, 282(1814), 20151546. https://doi.org/10.1098/rspb.2015.1546

Laurent, A. G. (1963). The Lognormal Distribution and the Translation Method: Description and Estimation Problems. Journal of the American Statistical Association, 58(301), 231-235. https://doi.org/10.1080/01621459.1963.10500844

Libralato, S., Coll, M., Tudela, S., Palomera, I., \& Pranovi, F. (2008). Novel index for quantification of ecosystem effects of fishing as removal of secondary production. Marine Ecology Progress Series, 355, 107-129. https://doi.org/10.3354/meps07224

Lindeman, R. L. (1942). The Trophic-Dynamic Aspect of Ecology. Ecology, 23(4), 399-417. https://doi.org/10.2307/1930126

This article is protected by copyright. All rights reserved 
Longhurst, A. R. (2007). Ecological geography of the sea (2nd ed). Amsterdam; Boston, MA: Academic Press.

Maureaud, A., Gascuel, D., Colléter, M., Palomares, M. L., Du Pontavice, H., Pauly, D., \& Cheung, W. W. (2017). Global change in the trophic functioning of marine food webs. PloS one, 12(8), e0182826.

Michel, C., Bluhm, B., Gallucci, V., Gaston, A. J., Gordillo, F. J. L., Gradinger, R., ... Nielsen, T. G. (2012). Biodiversity of Arctic marine ecosystems and responses to climate change. Biodiversity, 13(3-4), 200-214. https://doi.org/10.1080/14888386.2012.724048

Murphy, E. J., Cavanagh, R. D., Drinkwater, K. F., Grant, S. M., Heymans, J. J., Hofmann, E. E., ... Johnston, N. M. (2016). Understanding the structure and functioning of polar pelagic ecosystems to predict the impacts of change. Proceedings of the Royal Society B: Biological Sciences, 283(1844), 20161646. https://doi.org/10.1098/rspb.2016.1646

Niquil, N., Baeta, A., Marques, J., Chaalali, A., Lobry, J., \& Patrício, J. (2014). Reaction of an estuarine food web to disturbance: Lindeman's perspective. Marine Ecology Progress Series, 512, 141-154. https://doi.org/10.3354/meps10885

Odum, E. P. (1969). The Strategy of Ecosystem Development. Science, 164(3877), 262-270. https://doi.org/10.1126/science.164.3877.262

Palomares, M. L. D., \& Pauly, D. (1998). Predicting food consumption of fish populations as functions of mortality, food type, morphometrics, temperature and salinity. Marine and Freshwater Research, 49(5), 447. https://doi.org/10.1071/MF98015

Pauly, D., \& Christensen, V. (1995). Primary production required to sustain global fisheries. Nature, 374(6519), 255-257. https://doi.org/10.1038/374255a0

Pauly, Daniel, Hilborn, R., \& Branch, T. A. (2013). Fisheries : Does catch reflect abundance? Nature, 494(7437), 303.

Pauly, Daniel, \& Zeller, D. (2016). Catch reconstructions reveal that global marine fisheries catches are higher than reported and declining. Nature Communications, 7(1). https://doi.org/10.1038/ncomms 10244

Peck, L. S. (2016). A Cold Limit to Adaptation in the Sea. Trends in Ecology \& Evolution, 31(1), 13-26. https://doi.org/10.1016/j.tree.2015.09.014

Peck, L. S., Webb, K. E., \& Bailey, D. M. (2004). Extreme sensitivity of biological function to temperature in Antarctic marine species. Functional Ecology, 18(5), 625-630. https://doi.org/10.1111/j.0269-8463.2004.00903.x

This article is protected by copyright. All rights reserved 
Perry, A. L. (2005). Climate Change and Distribution Shifts in Marine Fishes. Science, 308(5730), 1912-1915. https://doi.org/10.1126/science.1111322

Perry, R. I., Cury, P., Brander, K., Jennings, S., Möllmann, C., \& Planque, B. (2010). Sensitivity of marine systems to climate and fishing: Concepts, issues and management responses. $\begin{array}{llll}\text { Journal of } \quad \text { Marine } \quad \text { 4ystems, } & \text { 79(3-4), }\end{array}$ https://doi.org/10.1016/j.jmarsys.2008.12.017

Pinsky, M. L., Worm, B., Fogarty, M. J., Sarmiento, J. L., \& Levin, S. A. (2013). Marine Taxa Track Local Climate Velocities. Science, 341(6151), 1239-1242. https://doi.org/10.1126/science.1239352

Pinsky, Malin L., Selden, R. L., \& Kitchel, Z. J. (2020). Climate-Driven Shifts in Marine Species Ranges: Scaling from Organisms to Communities. Annual Review of Marine Science, 12(1). https://doi.org/10.1146/annurev-marine-010419-010916

Planque, B., Fromentin, J.-M., Cury, P., Drinkwater, K. F., Jennings, S., Perry, R. I., \& Kifani, S. (2010). How does fishing alter marine populations and ecosystems sensitivity to climate?

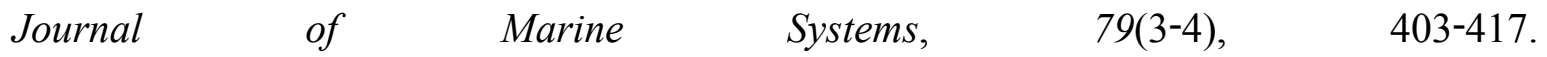
https://doi.org/10.1016/j.jmarsys.2008.12.018

Poloczanska, E. S., Brown, C. J., Sydeman, W. J., Kiessling, W., Schoeman, D. S., Moore, P. J., ... Richardson, A. J. (2013). Global imprint of climate change on marine life. Nature Climate Change, 3(10), 919-925. https://doi.org/10.1038/nclimate1958

Poloczanska, E. S., Burrows, M. T., Brown, C. J., García Molinos, J., Halpern, B. S., HoeghGuldberg, O., ... Sydeman, W. J. (2016). Responses of Marine Organisms to Climate Change across Oceans. Frontiers in Marine Science, 3. https://doi.org/10.3389/fmars.2016.00062

Pörtner, H. O., \& Farrell, A. P. (2008). ECOLOGY : Physiology and Climate Change. Science, 322(5902), 690-692. https://doi.org/10.1126/science.1163156

Pörtner, H. O., Karl, D. M., Boyd, P. W., Cheung, W. W. L., Lluch-Cota, S. E., Nojiri, Y., ... Zavialov, P. O. (2014). Ocean Systems. In Climate Change 2014 : Impacts, Adaptation, and Vulnerability. Part A: Global and Sectoral Aspects. Contribution of Working Group II to the Fifth Assessment Report of the Intergovernmental Panel on Climate Change (p. 411-484). [Field, C.B., V.R. Barros, D.J. Dokken, K.J. Mach, M.D. Mastrandrea, T.E. Bilir, M. Chatterjee, K.L. Ebi, Y.O. Estrada, R.C. Genova, B. Girma, E.S. Kissel, A.N. 
Levy, S. MacCracken, P.R. Mastrandrea, and L.L. White (eds.)]. Cambridge University Press, Cambridge, United Kingdom and New York, NY, USA.

Pörtner, H. O., Peck, L. S., \& Somero, G. N. (2012). Mechanisms Defining Thermal Limits and Adaptation in Marine Ectotherms : An Integrative View. In A. D. Rogers, N. M. Johnston, E. J. Murphy, \& A. Clarke (Éd.), Antarctic Ecosystems (p. 379-416). https://doi.org/10.1002/9781444347241.ch13

Pörtner, H. O., \& Peck, M. A. (2010). Climate change effects on fishes and fisheries: Towards a cause-and-effect understanding. Journal of Fish Biology, 77(8), 1745-1779. https://doi.org/10.1111/j.1095-8649.2010.02783.x

Pörtner, H. O., Storch, D., \& Heilmayer, O. (2005). Constraints and trade-offs in climatedependent adaptation: Energy budgets and growth in a latitudinal cline. Scientia Marina, 16.

Reygondeau, G., Longhurst, A., Martinez, E., Beaugrand, G., Antoine, D., \& Maury, O. (2013). Dynamic biogeochemical provinces in the global ocean: DYNAMIC BIOGEOCHEMICAL PROVINCES. Global Biogeochemical Cycles, 27(4), 1046-1058. https://doi.org/10.1002/gbc.20089

Ricklefs, R. E., \& Miller, G. L. (2000). Ecology (4th ed). New York: W.H. Freeman \& Co.

Schramski, J. R., Dell, A. I., Grady, J. M., Sibly, R. M., \& Brown, J. H. (2015). Metabolic theory predicts whole-ecosystem properties. Proceedings of the National Academy of Sciences, 112(8), 2617-2622. https://doi.org/10.1073/pnas.1423502112

Shephard, S., Fung, T., Houle, J. E., Farnsworth, K. D., Reid, D. G., \& Rossberg, A. G. (2012). Size-selective fishing drives species composition in the Celtic Sea. ICES Journal of Marine Science, 69(2), 223-234. https://doi.org/10.1093/icesjms/fsr200

Smetacek, V., \& Nicol, S. (2005). Polar ocean ecosystems in a changing world. Nature, 437(7057), 362-368. https://doi.org/10.1038/nature04161

Stock, C. A., John, J. G., Rykaczewski, R. R., Asch, R. G., Cheung, W. W. L., Dunne, J. P., ... Watson, R. A. (2017). Reconciling fisheries catch and ocean productivity. Proceedings of the National Academy of Sciences, 114(8), E1441-E1449. https://doi.org/10.1073/pnas.1610238114

Strayer, D. (1991). Notes on Lindeman's Progressive Efficiency. Ecology, 72(1), 348-350. https://doi.org/10.2307/1938928

This article is protected by copyright. All rights reserved 
Stuart-Smith, R. D., Edgar, G. J., Barrett, N. S., Kininmonth, S. J., \& Bates, A. E. (2015). Thermal biases and vulnerability to warming in the world's marine fauna. Nature. https://doi.org/10.1038/nature16144

Sunday, J. M., Bates, A. E., \& Dulvy, N. K. (2011). Global analysis of thermal tolerance and latitude in ectotherms. Proceedings of the Royal Society B: Biological Sciences, 278(1713), 1823-1830. https://doi.org/10.1098/rspb.2010.1295

Tittensor, D. P., Mora, C., Jetz, W., Lotze, H. K., Ricard, D., Berghe, E. V., \& Worm, B. (2010). Global patterns and predictors of marine biodiversity across taxa. Nature, 466(7310), 1098-1101. https://doi.org/10.1038/nature09329

Worm, B., \& Lotze, H. K. (2016). Marine Biodiversity and Climate Change. In Climate Change (p. 195-212). https://doi.org/10.1016/B978-0-444-63524-2.00013-0 
(a)
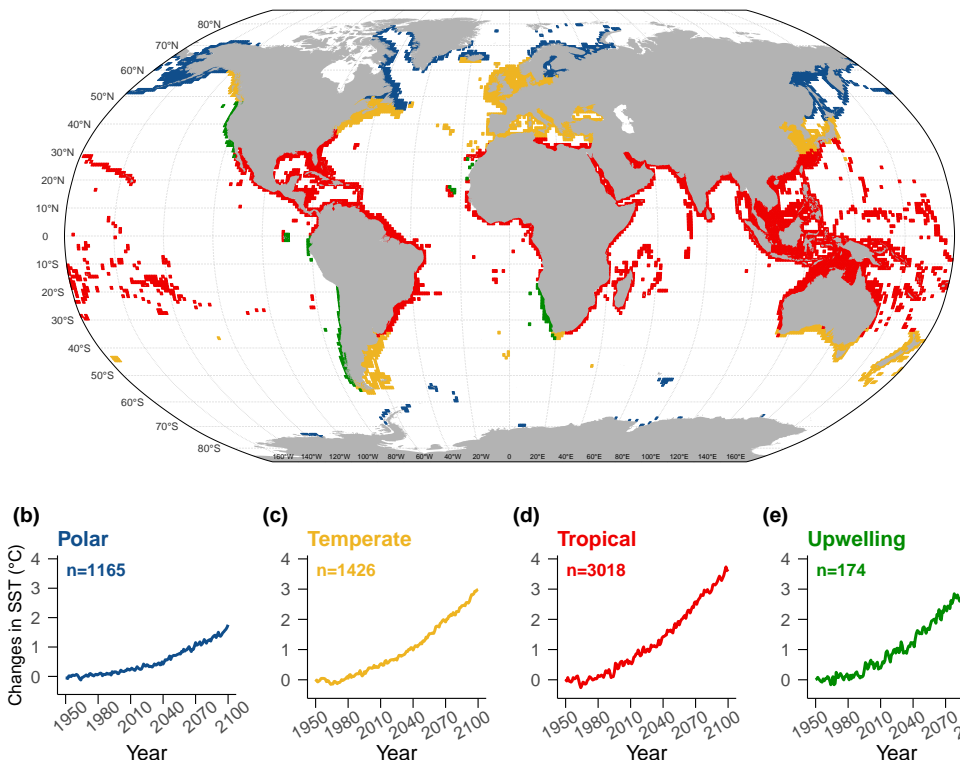

(c)

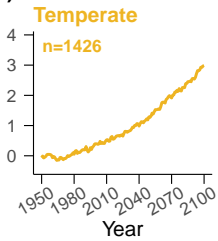

(d)

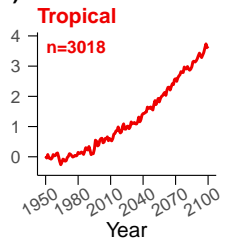

(e)

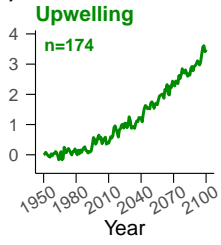



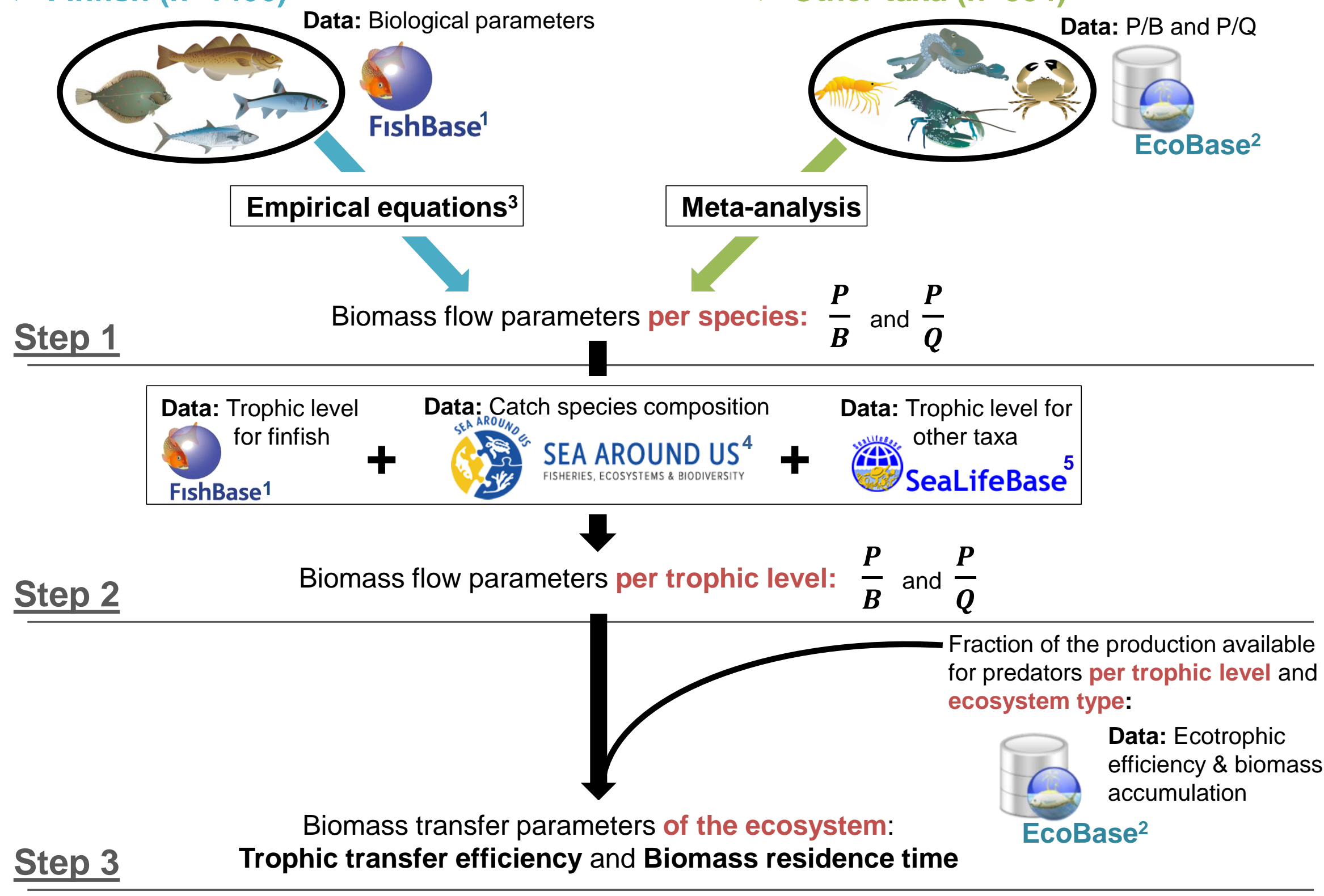
Non-predation mortality (1-EE), biomass accumulation (Bacc)
Metabolism losses (Respiration, excretion...)

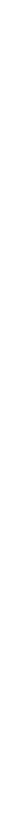




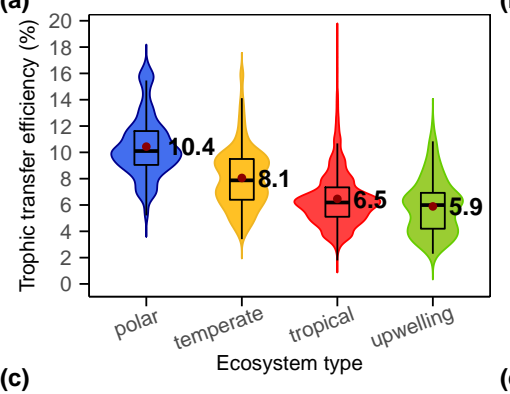

(b)

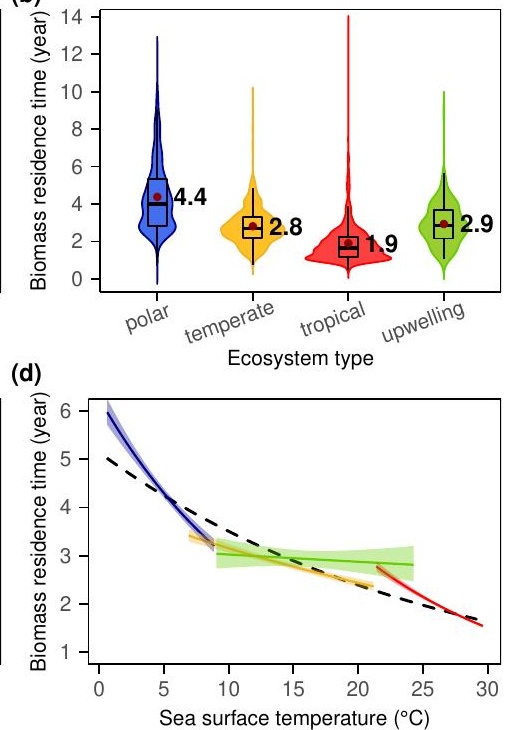

(d)

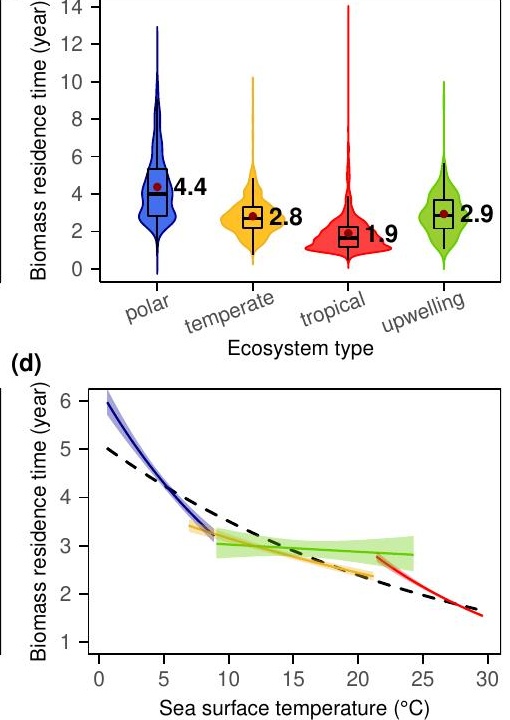

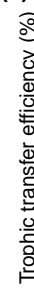

(a)

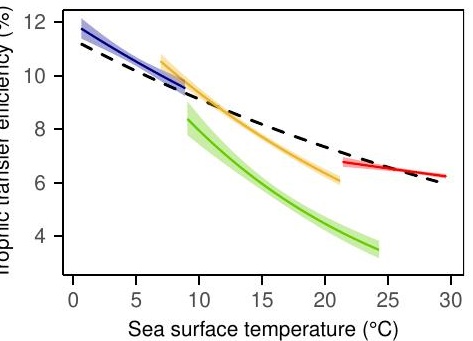




\section{Trophic transfer efficiency}

(a)

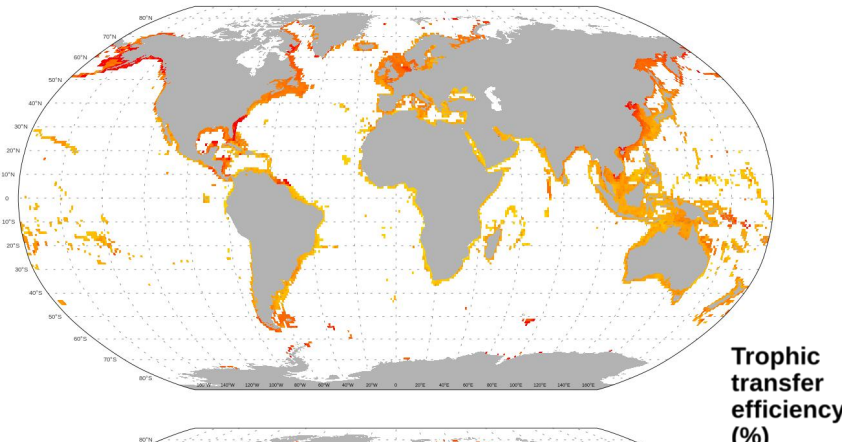

(c)

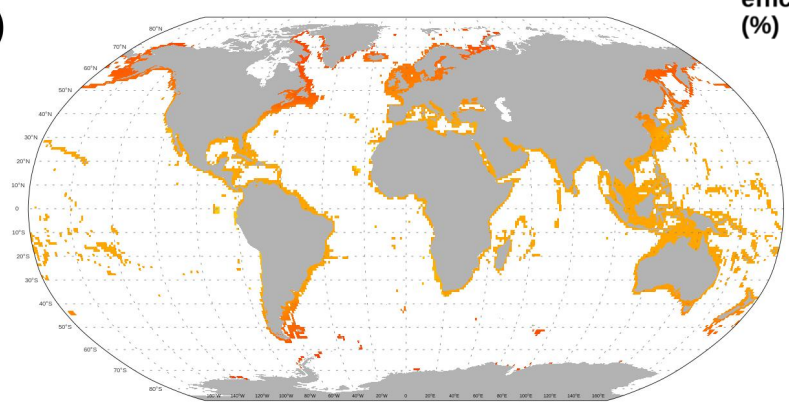

(e)

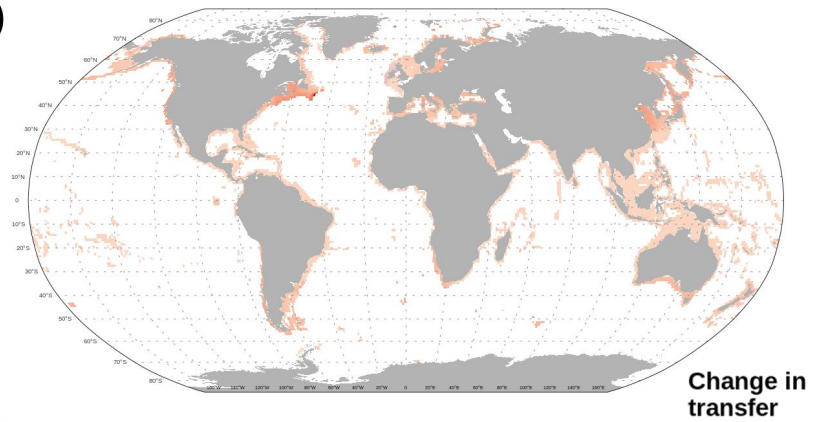

(g)

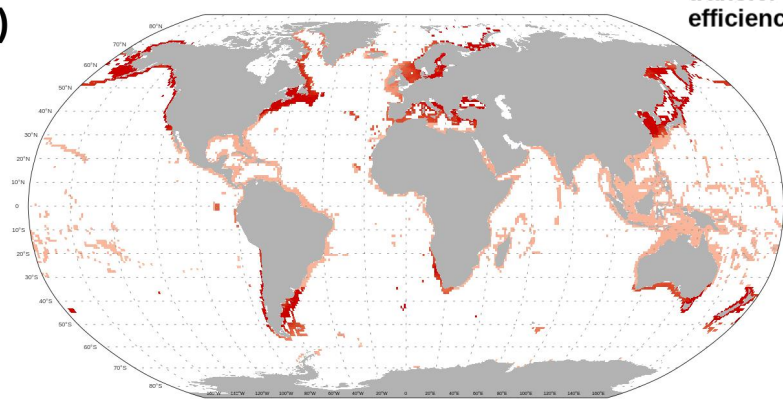

\section{Biomass residence time}
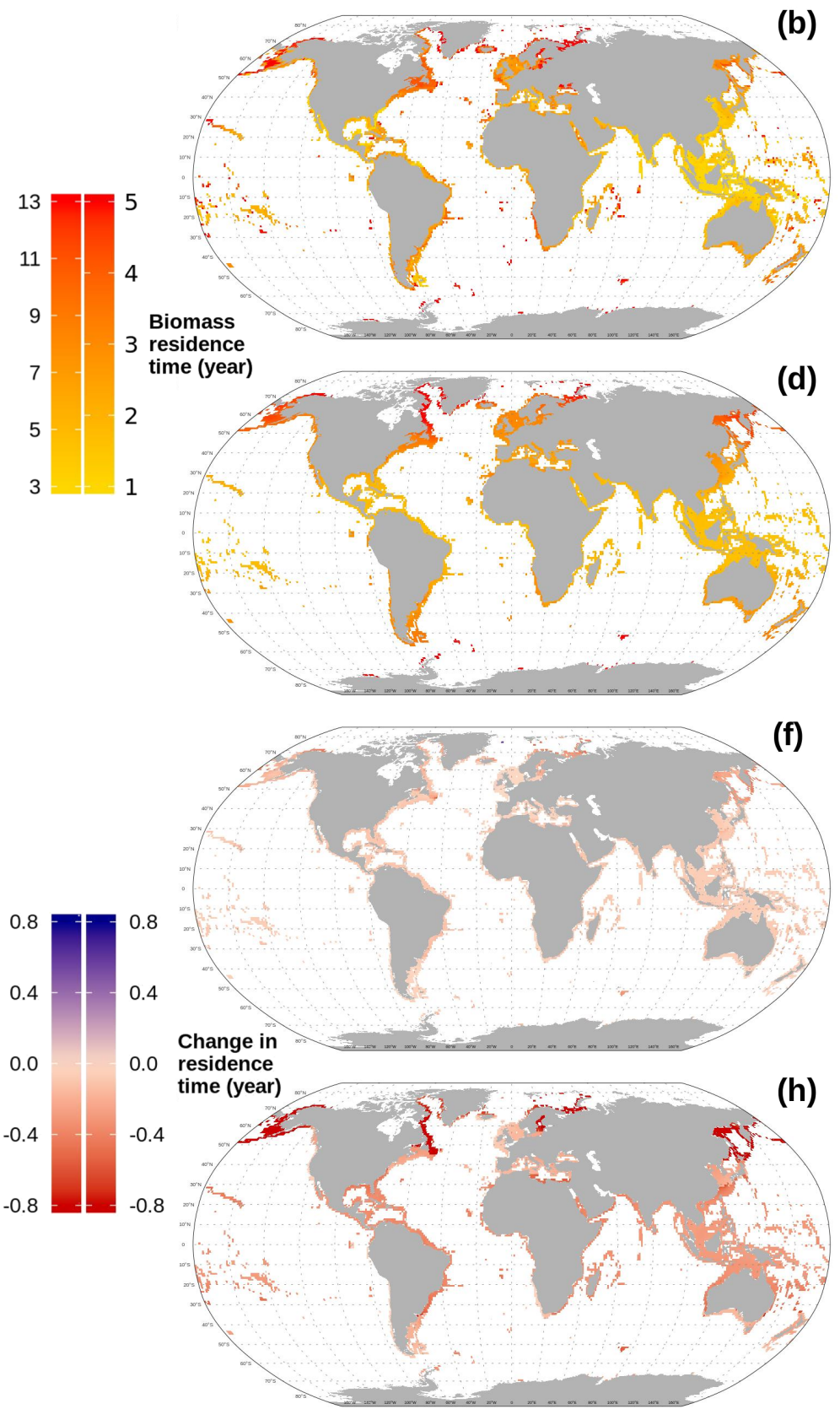


\section{(a)}

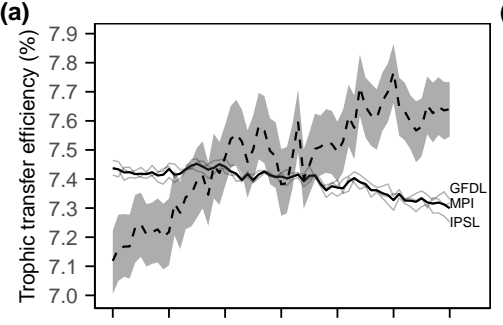

1950196019701980199020002010 Year

(b)

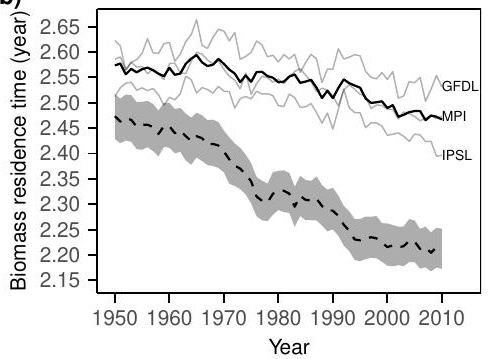


